\title{
Evaluation Training Effect System of College Counselors Based on Kirkpatrick Model
}

\author{
Yuyan Zhou \\ Student Affairs Department, Wuhan Textile University, Wuhan 430200, China \\ wtuxsc@163.com
}

Keyword: Evaluation; College counselors; Kirkpatrick model

\begin{abstract}
At present, the college counselor training scale is growing day by day, but evaluation training effect system is relatively low. It mainly exists to assess understanding does not reach the designated position, incomprehension about evaluation content, relatively single evaluation and evaluation results into problems such as less. In this paper, Kirkpatrick model is used to analyze and reconstruct the system from the four levels of reaction, learning, behavior and result in current situation. It is hoped that continue improvement of this work on training effectiveness, the overall system of students' affairs work will continue to improve effectively more and more. It is proposed that the integration of the four levels, the tracking of long-term data, quantifiable index and result-oriented feedback for the evaluation.
\end{abstract}

\section{Introduction}

Newly revised <Regulations on the construction of counselors of ordinary colleges and universities >explicitly pointed out: college is responsible for the counselor system training, to ensure that education or training take up no less than 16 hours in every year [1]. With the increase of the training scale of college counselors, the training of various kinds of subjects has increased significantly, and how to evaluate the effect is the necessary link to further optimize and improve the instructor training. Therefore, it is necessary to carry out further research on the training effect evaluation of counselors, combine the training completion assessment with the school assessment, and establish a set of evaluation model with operational and systematic integration.

\section{The Main Problem of the College Counselor Training Effect Evaluation}

Low Participation Rate About Evaluation System and Misunderstanding. The complete training process starts with needs analysis, training plan, implementation of training activities, and training effect assessment. The results of the training effect assessment will directly affect the development of the new training program. Training for college counselors is always carried out from the top to down. The counselors have to accept it, and there is no opportunity to participate in training teaching design, learning management and information feedback [2].

In the current and extensive training assessment theory, Kirkpatrick Model from the University of Wisconsin has suggested that the class 4 is the most representative. He thinks the project indicate the direction for subsequent training. There are the Principles of Kirkpatrick Model and evaluation points [3].

Level 1: Reaction. The degree to which participated find the training favorable, engaging and relevant to their jobs.

Level 2: Learning. The degree to which participated acquire the intended knowledge, skills, attitude, confidence and commitment based on their participation in the training.

Level 3: Behavior. The degree to which participated apply what they learned in training when they are back on the job.

The Training Assessment is Less Relevant and Fuzzy Content. Evaluation is based on job analysis, job description, performance management, training learning and professional development. In fact, there is no promotion between the training content of the instructor and the student affairs or 
daily performance, and there is less correlation between the implementation of individual rewards and punishments, the difference of the next round of training objectives and the effectiveness of learning. at last, training is only a opportunity to expand the cognitive, is no good use for career advancement.

The Assessment Form is Single and the Assessment Results are Limited. So far, the evaluation of training effect of college counselors is still in the primary stage. We usually assess and respond to participation, learning experience and theme exchange in the training department. There was no activity in the training session, no follow-up, no follow-up, etc. The new knowledge, skills and theories that the college counselors have been trained to gain in training was not be valid. These have leaded to the overall assessment of the training effect still in the surface.

\section{Theoretical Bases}

Level 4: Results. The degree to which targeted outcomes as a result of the training and the support and accountability package.

\section{Re-engineering about Evaluation Model}

According to the actual situation, the information about the job environment and career development of counselors, the new model (Fig.1) to evaluate the training effect of counselors adhere to the principle of combining assessment in training process and assessment of effectiveness after training. It inspects the teacher's knowledge structure, from a number of operation and abilities about students' affairs.

Reaction Evaluation. It focuses on counselors' subjective views and understanding of the training activities. Such as, satisfaction of the training program, can survey training personnel from evaluate training implementation. It's about how you feel about the course, whether it's appropriate to appraise it or how to advise.

Learning Evaluation. Checking degree of learning for college counselors is the key of evaluation model. It will direct impact on performance. We can find from what knowledge, skills, master degree, improve their work ability, work attitude, etc in the training.

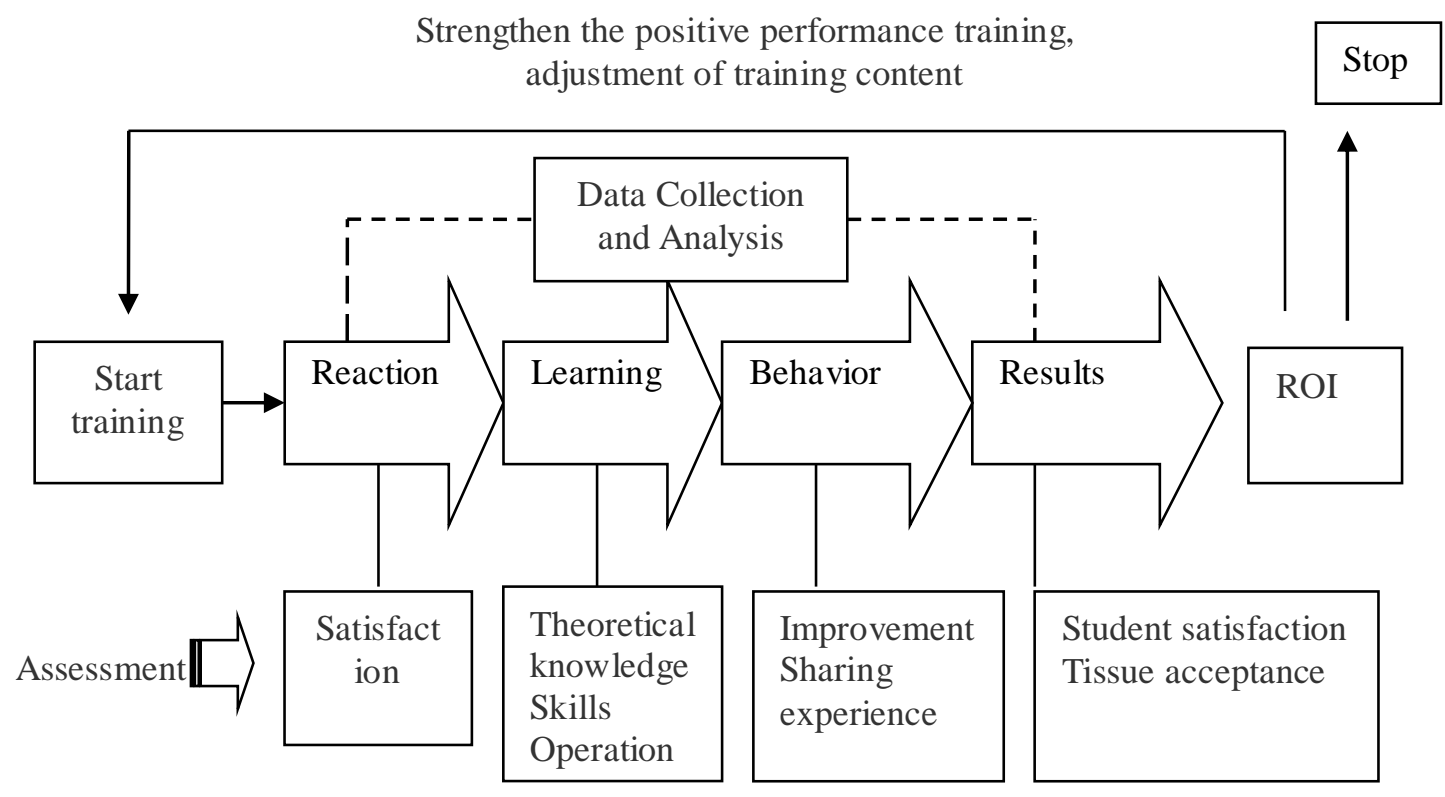

Figure 1. Process of evaluating College Counselors' training effect

Behavior Evaluation. It focuses on difference with college counselors' work that the students' guidance behavior, work philosophy and other aspects have improved after the training. This measure can comprehensively examine the impact of training on actual work. It connects ideas, 
knowledge, and operative skills to the state of the work, and indirectly to the result level [4].

Results Evaluation. It need analyze the benefits of university organizers and individuals participating in the training. The output ratio of the individual and the organization is the key index to improve the quality and reliability of training. This will provide strong support for the continuing development of training activities [5].

\section{Implementation Suggestions}

According to the practical and the new process of evaluating system, it is divided in terms of the reaction, learning cognition, behavior, individual and organizational performance. Each level of system has been linked to the cognitive work of training, knowledge, skills, results, student satisfaction and so on (Table 1). The system also gives a specific review of time procedure and assessors based on the specific evaluation. It is hoped that continue improvement of this work on training effectiveness, the overall system of students' affairs work will continue to improve effectively more and more. The following are some points for implementation of the system.

Attention to the Integration Between These Four Types of Modules. Introduction of systems thinking need focus on the impact of each module on the overall output of the training, put the training in priority.

Enhance the communication between the training organizer and the participants. It need comprehensively consider the assessment results of different aspects of leadership, students, colleagues and others.

Table 1 Evaluation Training Effect System of the College Counselor Based on Kirkpatrick Model

\begin{tabular}{|c|c|c|c|c|}
\hline $\begin{array}{c}\text { Leve } \\
\text { l }\end{array}$ & Context & Procedure & Time & Assessor \\
\hline 1 & $\begin{array}{l}\text { Satisfaction } \\
\text { with training } \\
\text { content, } \\
\text { lecturers and } \\
\text { teaching } \\
\text { forms }\end{array}$ & $\begin{array}{l}\text { Questionnaire, } \\
\text { on - site observation } \\
\text { and interview } \\
\text { method, etc }\end{array}$ & $\begin{array}{l}\text { Training } \\
\text { finishing }\end{array}$ & Trainer \\
\hline 2 & $\begin{array}{l}\text { Understanding } \\
\text { and mastery of } \\
\text { training } \\
\text { knowledge, } \\
\text { skills or } \\
\text { Operation }\end{array}$ & $\begin{array}{l}\text { Examination, } \\
\text { theme speaking, } \\
\text { writing reviews, } \\
\text { discussion and } \\
\text { scenario simulation } \\
\text { demonstration, etc }\end{array}$ & $\begin{array}{l}\text { At the time } \\
\text { of the course } \\
\text { or after }\end{array}$ & $\begin{array}{l}\text { Lecturer } \\
\text { Training Organizer }\end{array}$ \\
\hline 3 & $\begin{array}{l}\text { Improvement } \\
\text { Sharing } \\
\text { experience }\end{array}$ & $\begin{array}{l}\text { Questionnaires, } \\
\text { Behavioral } \\
\text { observations, } \\
\text { interviews and } \\
\text { 360-degree } \\
\text { performance Appraisal }\end{array}$ & $\begin{array}{l}\text { After } \\
\text { Training }\end{array}$ & $\begin{array}{l}\text { Worker in Student } \\
\text { Affairs Section, Team } \\
\text { leaders, colleagues and } \\
\text { students }\end{array}$ \\
\hline 4 & $\begin{array}{l}\text { Student } \\
\text { satisfaction } \\
\text { Tissue } \\
\text { acceptance }\end{array}$ & $\begin{array}{l}\text { Student Satisfaction } \\
\text { Survey, Achievement } \\
\text { Assessment }\end{array}$ & $\begin{array}{l}\text { Assessment } \\
\text { in one year } \\
\text { after training }\end{array}$ & $\begin{array}{l}\text { Student committee in } \\
\text { College、Worker in } \\
\text { Student Affairs Section, } \\
\text { division } \\
\text { head,colleagues and } \\
\text { students }\end{array}$ \\
\hline
\end{tabular}

Long-term Data Tracking

Establish training database. It will contain relevant data for all counselors. Such as daily work 
performance, awards, investigations or researches, paper achievements and features.

Analysis changes in a period. It need compare the data that before and after training, find out his career changes over a certain period of time.

Share information between training providers and school. By compare the performance of counselor during the training session and the daily practice, we can get more valuable evaluation results [6].

\section{The Quantitative Index of Evaluation}

The description of the evaluation index should be as clear as possible. For example, the management behavior of counselors should be defined, and given the value of the corresponding proportion in the behavioral assessment module.

The overall performance and part of the operation should be graded separately. The familiarity of the overall process is graded while scoring separately for each operation in the learning module evaluation. The effect of studying can reflect more comprehensive evaluation of counselor.

Result-oriented Feedback. The final evaluation results must be returned to the training organizers, school and trainees, so as to provide information for further decisions. In accordance with timely and correct feedback, the school continually optimizes training content and projects, actively creates better working environment that promotes the transformation of training results, put the learning knowledge and skills to be applied to the actual work.

The feedback of evaluation results can helps the participation counselors to correct their weaknesses and work hard. They should clearly understand their learning effect whether meets the requirements of student affairs, understand advantages and disadvantages about themselves. In this way, we can continuously improve vocational ability of counselors and be able to work well year by year.

\section{Acknowledgements}

This article is the initial results of the Hubei College Student Work Research Project supported Study on the improvement route of the professional ability of the college counselor under the guidance of innovation (No.1617YA06) and Wuhan Textile University Foundation named The path exploration of the theoretical literacy of the ideological and political education of the college counselor. (No.163097).

\section{References}

[1] Information on http://www.moe.edu.cn/ (In Chinese)

[2] Bo Liu: The Research of Competency Maturity (SC-MM) model, Nanjing university of technology Publications (2013), pp23-28.(In Chinese)

[3] Kirkpatrick Donald L: Training Programs, The Four Levels. Barrett - Koehler Organizational Performance Series. Journal for Nurses in Professional Development (1994) 30, pg83.

[4] X.Y. Fan and J.Y. Xu, Study on the Competency Training System of College Counselors, Ideological Education Research (2015)No.1, pg24.(In Chinese)

[5] Jian Liu, The Research about Evaluate Construction of College Counselors' Training Effect, Chinese Adult Education (2014)No.12, pg28.(In Chinese)

[6] N. Zhou and X.L. Jin: The Evaluation Model of Secondary Vocational School Teachers' Training Based on the Kirkpatrick Theory, Professional Education Research;(2017)No.8,pg39-43.(In Chinese) 